\title{
CONTENTS
}

\section{MEDIEVAL PHILOSOPHY}

Andriy Baumeister (Kiev) The light of Intellect and the light of glory:

metaphysics of knowledge in St. Thomas Aquinas

\section{MODERN PHILOSOPHY}

Sergiy Shevtsov (Odessa) Two Fragments by Leibniz about Freedom .42

\section{PHILOSOPHY OF XIXth CENTURY}

Oleksiy Panych (Donetsk) John Stuart Mill against William Hamilton: a struggle for philosophical heritage of British Empiricism 55

\section{PHILOSOPHY OF XXth CENTURY}

Andriy Dakhniy (Lviv) Establishment of existentially-temporal problematics in Martin Heidegger's philosophy: Marburg lecture «The concept of time» (1924) 64

\section{PANORAMA}

Boris Dombrovskiy (Lviv) The Tower of Babel as an example of reism 79

\section{EASTERN EUROPE}

Vsevolod Kuznetsov, Liubov Nerusheva (Vinnytsia) Solovyov's Followers: Virtual Love after Andrey Bely....

\section{TOOLS}

Natalie Depraz (France) Animal

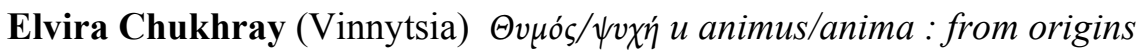
to classic forms. 
Oleg Khoma (Vinnytsia) Animus/anima, animus/mens: accumulation of untranslatability

\section{PRIMARY SOURCES}

Karol Wojtyla The Personality Structure of Self-Determination 156

Inna Savynska (Kyiv) The experience of the personal act according to Karol Wojtyla's theory 164

Maria Alchuk (Lviv) Problems of the Philosophy of Right in the Bohdan Kistyakivsky's thesis "Gesellschaft und Einzelwesen...».... 